\title{
Patterns of landscape and assemblage structure along a latitudinal gradient in ocean climate
}

\author{
Fernando Tuya ${ }^{1,2, *}$, Eva Cacabelos ${ }^{1}$, Pedro Duarte ${ }^{1,3}$, David Jacinto ${ }^{4}$, João J. Castro ${ }^{4}$, \\ Teresa Silva ${ }^{4}$, Iacopo Bertocci ${ }^{1}$, Joao N. Franco ${ }^{1}$, Francisco Arenas ${ }^{1}$, Josep Coca ${ }^{5}$, \\ Thomas Wernberg ${ }^{6,7}$ \\ ${ }^{1}$ CIIMAR, Rua dos Bragas 289, 4050-123 Porto, Portugal \\ ${ }^{2}$ BIOGES, Universidad de Las Palmas de Gran Canaria, 35017, Canary Islands, Spain \\ ${ }^{3}$ CIAGEB, Faculty of Science and Technology, University Fernando Pessoa, Porto 4249-004, Portugal \\ ${ }^{4}$ Laboratório de Ciências do Mar, Universidade de Évora, 7521-903 Sines, Portugal \\ Centro de Oceanografia, Faculdade de Ciências da Universidade de Lisboa, Lisboa 1749-016, Portugal \\ ${ }^{5}$ ROC-IUSIANI, Universidad de Las Palmas de Gran Canaria, 35017, Canary Islands, Spain \\ ${ }^{6}$ School of Plant Biology \& UWA Oceans Institute (M096), University of Western Australia, Crawley, Western Australia 6009, \\ Australia \\ ${ }^{7}$ Australian Institute of Marine Science, 39 Fairway, Crawley, Western Australia 6009, Australia
}

\begin{abstract}
The Portuguese coast has overlapping distributions of species of both boreal and Lusitanian origins; a large number of cold- and warm-water species have their southern or northern distributional range edges here. A latitudinal gradient in ocean climate, particularly sea surface temperature (SST) and primary production, has been described along this coast. Here, we took advantage of this gradient in ocean climate to explore affinities in the biogenic landscape structure of subtidal shallow reefs (the abundance of habitat patches), as well as in the assemblage structure of macroalgae and associated fishes, between each of 3 regions: Viana do Castelo $\left(41.5^{\circ} \mathrm{N}\right)$, Peniche $\left(39.2^{\circ} \mathrm{N}\right)$ and Sines $\left(37.8^{\circ} \mathrm{N}\right)$. Five reefs were sampled to determine the abundance of biogenic habitats and the assemblage structure of macroalgae and fishes in each region. The structure of the landscape, and of macroalgal and fish assemblages, differed between Viana do Castelo and Peniche and between Viana do Castelo and Sines, but not between Peniche and Sines. Viana do Castelo was the only region with conspicuous kelp forests, while Peniche and Sines were dominated by patches of foliose turf-forming and filamentous algae. Our study revealed an abrupt macroecological change from northern Portugal to central and southern Portugal, suggesting a possible biogeographical reconfiguration and recognition of a wider transitional area from the Atlantic into Mediterranean waters.
\end{abstract}

KEY WORDS: Latitude $\cdot$ Macroecology $\cdot$ Habitat structure $\cdot$ Assemblage structure $\cdot$ Kelps $\cdot$ Fishes Rocky reefs · Atlantic Ocean

\section{INTRODUCTION}

Most species vary in their ecology across latitude in response to large-scale environmental variability (Brown 1984); these responses include changes in demography (Boyce 1978, Wernberg et al. 2010, 2011a). Describing such large-scale patterns, and elucidating the processes that create them, can make an important contribution to ecology, evolutionary biology, and conservation (Briggs 1974, Lüning 1990, Roy et al. 1998). For example, understanding how latitudinal gradients in climatic variables influence the 
distribution, abundance and fitness of organisms may be relevant for predicting the effects of climate change, because shifts in distribution patterns along these gradients are among the principal detectable responses to climate change by both aquatic and terrestrial organisms (Southward et al. 1995, Walther et al. 2002, Parmesan \& Yohe 2003, Poloczanska et al. 2007, Hawkins et al. 2009, Wernberg et al. 2011b, 2012).

In the marine realm, biogeographic classifications are a crucial tool for reaching international agreements in marine conservation. Biogeographic units have been defined using sets of hierarchical criteria, within which the biogeographic affinities of biological entities and assemblages are a key component (Lüning 1990, Spalding et al. 2007). Considerable heterogeneity in the composition and abundance of biological communities may exist within any particular biogeographic level, mainly within large spatial units, and so a more detailed classification system is recommended (Spalding et al. 2007, Waters et al. 2010). This is particularly pertinent as shifts in the distributional ranges of several species are occurring in most oceans of the globe as a result of global change (e.g. Southward et al. 1995, Last et al. 2011, Philippart et al. 2011, Wernberg et al. 2012). In this context, it is crucial to test whether biogeographical affinities at distinct levels of biological organization are consistent within biogeographical units. At a landscape level, there are several habitat types that vary in composition, extent and patchiness at local to biogeographical scales (Connell \& Irving 2008, Wernberg et al. 2011a), while individual species may respond to compounded changes in environmental conditions and/or habitat structure, causing changes in the composition, diversity and abundance of assemblages (Brown \& Maurer 1989, Lüning 1990, Witman \& Roy 2009).

Landscapes dominated by macroalgae are conspicuous elements of many temperate coasts (Lüning 1990). These landscapes are often irregular mosaics of distinct habitats, providing a complex set of interspersed physical and biological environments that affect the development and maintenance of the associated fauna, including invertebrate (e.g. Dayton et al. 1992, Tuya et al. 2008) and fish assemblages (e.g. Tuya et al. 2009, 2011).

The coast along continental Portugal has overlapping distributions of species of both boreal and Lusitanian origins (Southward et al. 1995, Lima et al. 2007) and is included within the South European Atlantic Shelf ecoregion (Spalding et al. 2007). A large number of cold- and warm-water species have their southern or northern distributional range edges along this stretch of coastline (Fischer-Piette \& Prenant 1957, Ardré 1971, Lima et al. 2007), while other species show latitudinal clines in abundance (Santos 2000, Boaventura et al. 2002, Lima et al. 2006, Pereira et al. 2006). Latitudinal gradients in ocean climate, particularly year-round seawater temperature and primary production (Peliz \& Fiúza 1999, Lemos \& Pires 2004) have been highlighted as an explanation for these macroecological patterns, which are exacerbated by intense upwelling events during the warm season (Lima et al. 2007). Relaxation of the upwelling has been shown to cause shifts in species distributions (Lima et al. 2006). Here, we took advantage of this gradient in ocean climate to explore latitudinal affinities in the biogenic landscape structure of subtidal shallow reefs, defined as the relative abundance of habitats (sensu Wernberg et al. 2011a), as well as in the assemblage structure of macroalgae and associated fishes. These results raise questions about the adequacy of current biogeographical configurations for this region and an alternative model is suggested.

\section{MATERIALS AND METHODS}

\section{Field sampling design}

This study included 3 regions across continental Portugal: Viana do Castelo (VIA), Peniche (PEN) and Sines (SIN) (Fig. 1) across $\sim 5^{\circ}$ latitude. Each region included a stretch of coast between 10 and $20 \mathrm{~km}$ long. This coastline is almost rectilinearly oriented from north to south, maintaining a similar overall exposure to dominant NW and W swells among regions. The shore is characterized by extensive sandy beaches interspersed with limestone, sandstone, shale or granitic reefs in both the intertidal and the shallow subtidal. Within each region, 5 rocky (mostly granitic at VIA and PEN and shale and sandstone at SIN) reefs, 1 to $5 \mathrm{~km}$ apart, at 6 to $11 \mathrm{~m}$ depth, were selected randomly. All reefs were outside no-take areas, and all sampling was done during summer 2011 (VIA: 2 to 20 June; PEN: 14 to 17 June; SIN: 12 August and 2 September).

\section{Oceanographic patterns}

Sea surface temperature (SST) and chlorophyll a (chl a) concentration data were acquired from 


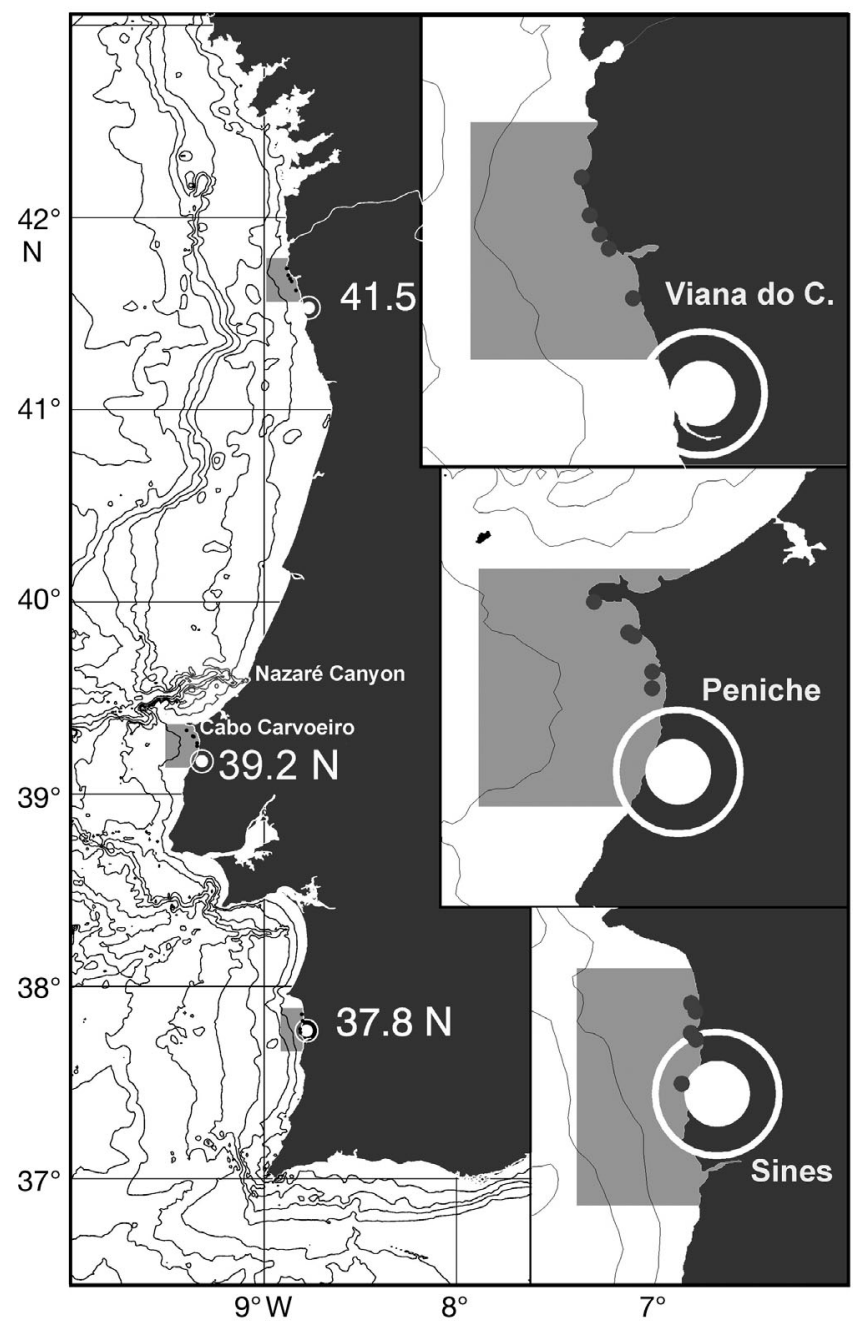

Fig. 1. Bathymetric map of continental Portugal showing location of the 3 study regions: Viana do Castelo $\left(41.5^{\circ} \mathrm{N}\right)$, Peniche $\left(39.2^{\circ} \mathrm{N}\right)$ and Sines $\left(37.8^{\circ} \mathrm{N}\right)$, and the 5 reefs (grey dots in insets) sampled in each region

monthly Level-3 Standard Mapped Image files generated by the MODIS Aqua sensor, available on NASA's Ocean Color Web (oceancolor.gsfc.nasa. gov/). The SST4 product was selected for SST data, which corresponds to SST derived from near infrared bands detected by the MODIS sensor during nighttime. Data files in HDF format were extracted from pixels that encompass all reefs within each study region from monthly images produced from January of 2003 to July 2011. During field work (see below), water samples $(n=3)$ were collected on each reef, approximately $1 \mathrm{~m}$ above the bottom and immediately filtered and stored on ice until return to land. Samples were then frozen $\left(-20^{\circ} \mathrm{C}\right)$ until chemical analysis for nutrients (phosphates, nitrates and ammonia) using a Skalar autoanalyzer.

\section{Landscape structure and kelp densities}

The overall biogenic landscape structure of each reef was quantified by running six $25 \times 2 \mathrm{~m}$ transects along haphazard compass bearings and recording the distances (to nearest $10 \mathrm{~cm}$ ) of habitat change. This technique has previously been successfully applied to describe habitat structure on rocky subtidal habitats (Connell \& Irving 2008, Wernberg et al. 2011a). We distinguished between 3 major algal habitat types: (1) kelp (forest) canopy (>90\% constituted by either Laminaria hyperborea, L. ochroleuca, Sacchoriza polyschides or Phyllariopsis spp.); (2) foliose turfforming algae (including non-crustose calcareous species, e.g. Asparagopsis armata, Dyctiota dichotoma, Plocamium cartilagineum, and calcareous species, e.g. Corallina officinalis), usually from 5 to $15 \mathrm{~cm}$ in height, which typically constitute multispecies thin sheets or bush-like patches; and (3) filamentous algae, usually $<5 \mathrm{~cm}$ in height (e.g. Heterosiphonia plumosa, Pterosiphonia spp, Polysiphonia denudata) (Tuya \& Haroun 2006). In addition, 2 types of habitats lacking erect algae were identified: (4) barren areas, i.e. patches devoid of erect vegetation as a result of intense grazing by sea urchins, particularly Paracentrotus lividus, and covered by crustose coralline algae; and (5) filter feeders patches, usually dominated by actinians (e.g. Anemonia viridis) and soft corals. The distinctions between these habitat types were based on previous studies documenting how they affect their immediate surroundings differently and support different associated phytal, sessile and mobile assemblages (Wernberg et al. 2005, Irving \& Connell 2006, Tuya et al. 2008); the adopted classification has been previously tested and implemented in the study area (Tuya \& Duarte 2012). The density of kelp species was also counted at all reefs along each transect, since kelps are key elements of shallow subtidal temperate reefs determining overall community structure (Schiel \& Foster 1986, Graham 2004, Irving \& Connell 2006, Wernberg et al. 2011a). To take account of any concurrent changes in biogenic landscape structure of reefs with changes in reef bottom topography, we also noted, along each transect, the extent of each of 3 bottom (substratum) categories: reef plateau, boulders and pebbles, as percentages relative to the total $25 \mathrm{~m}$ length of the transect.

\section{Algal assemblages}

At each reef, we harvested all vegetation from $6 \times$ $0.25 \mathrm{~m}^{2}$ quadrats randomly deployed on horizontal 
reef surfaces; samples were then frozen until processed in the lab. All algae within each sample were identified to the lowest feasible taxonomic level, mostly species, and weighed (wet weight after shaking for excess water). Algal species were assigned to 2 bioclimatic groups: 'cold-water' Atlantic boreal species and 'warm-water' Lusitanian species (Table S1 in the supplement at www.int-res.com/articles/suppl/ m466p009_supp.pdf), based on algal classifications for the northern Atlantic (Alvarez et al. 1988, Lüning 1990), as well as on the historical distribution of algae along the coasts of Europe and North Africa and the presence of southern or northern distribution limits on the Portuguese or adjacent Spanish coasts (Ardré 1971, Barbará et al. 2005, Lima et al. 2007, Araújo et al. 2009). A third group, 'widely distributed' species, included the considerable number of algae that have broad distribution ranges across the Atlantic.

\section{Fish assemblages}

Fishes were surveyed at each reef through 5 randomly oriented $25 \times 4 \mathrm{~m}$ belt transects by SCUBA divers, who identified, mostly to species level, and counted all adult and sub-adult fishes during transect tape deployment. When rolling up the transect, divers counted the number of large $(>1 \mathrm{~m})$ and small $(<1 \mathrm{~m})$ topographic elements of the rocky substrata (i.e. cracks, crevices, caves, holes) (Tuya et al. 2008). Fishes were classified in 2 bioclimatic groups: coldwater boreal fishes and warm-water Lusitanian fishes (Table S2 in the supplement), following previous categorizations for the eastern Atlantic (Wheeler et al. 2004, ter Hofstede \& Rijnsdorp 2011) and taking into account their distributional ranges across the eastern Atlantic (Froese \& Pauly 2008). Boreal coldwater fishes are absent, or present sporadically, in the Mediterranean. Two species with broad, amphiAtlantic distributions were classified as widely distributed species.

\section{Statistical analyses}

Pearson product moment correlation (r) was used to describe the relationship between the mean values of oceanographic variables per region (SST, chl a and nutrient concentrations) and latitude. Non-metric multi-dimensional scaling (NMDS) was used to visualize differences in landscape and algal and fish assemblage structure among regions, while differences were tested by 2-way mixed PERMANOVA
(Anderson 2001), with Region as fixed factor and Reef as a random factor nested within Region. The calculated proportional measures of the extent of each bottom category were included as covariates in the permutational multivariate analysis of variance (PERMANOVA) model testing for differences in biogenic landscape structure, in order to remove the potential effect of the local reef topography that may confound biogeographic responses (i.e. differences among regions). Similarly, we included the number of large and small topographic elements of the rocky substrate as covariates for the PERMANOVA testing for differences in reef fish assemblage structure, in order to remove the effect of local influences (reef local 'architecture') that could potentially mask fish biogeographic responses. Analyses were based on Bray-Curtis dissimilarities from square-root transformed abundance data. All multivariate procedures were carried out using the PRIMER 6.0 \& PERMANOVA package (Anderson et al. 2008); for all analyses, p-values were calculated using 4999 permutations. Finally, differences in the density of kelp species (univariate responses) among regions and reefs were tested by 2-way ANOVA, applied to the same model outlined above. No transformation rendered variances homogeneous (Cochran's test, $\mathrm{p}<0.05$ for all types of transformation). The significance level in these tests was, however, set at 0.01 instead of 0.05 to compensate for the increased probability of Type I error (Underwood 1997). Differences in the proportion between coldwater and warm-water algal and fish species among regions were tested by chi-square $\left(\chi_{1}^{2}\right)$ tests.

\section{RESULTS}

\section{Oceanographic patterns}

The 3 regions span a year-round latitudinal gradient in SST of $\sim 1$ to $2^{\circ} \mathrm{C}$ (Fig. $2 \mathrm{~A}, \mathrm{r}=-0.99, \mathrm{n}=3, \mathrm{p}<$ 0.01). Latitudinal gradients also occurred in both chl a (Fig. 2B, r = 0.98, p < 0.01), nutrient concentrations of phosphates $(\mathrm{r}=0.91, \mathrm{n}=3, \mathrm{p}<0.01)$ and ammonia $(\mathrm{r}=0.99, \mathrm{n}=3, \mathrm{p}<0.01)$; only nitrate concentration did not show a significant correlation with latitude ( $\mathrm{r}=0.50, \mathrm{n}=3, \mathrm{p}>0.05$ ) (Fig. $2 \mathrm{C}$ ).

\section{Landscape structure and kelp densities}

The biogenic structure of subtidal reefs differed between VIA and PEN, and between VIA and SIN 

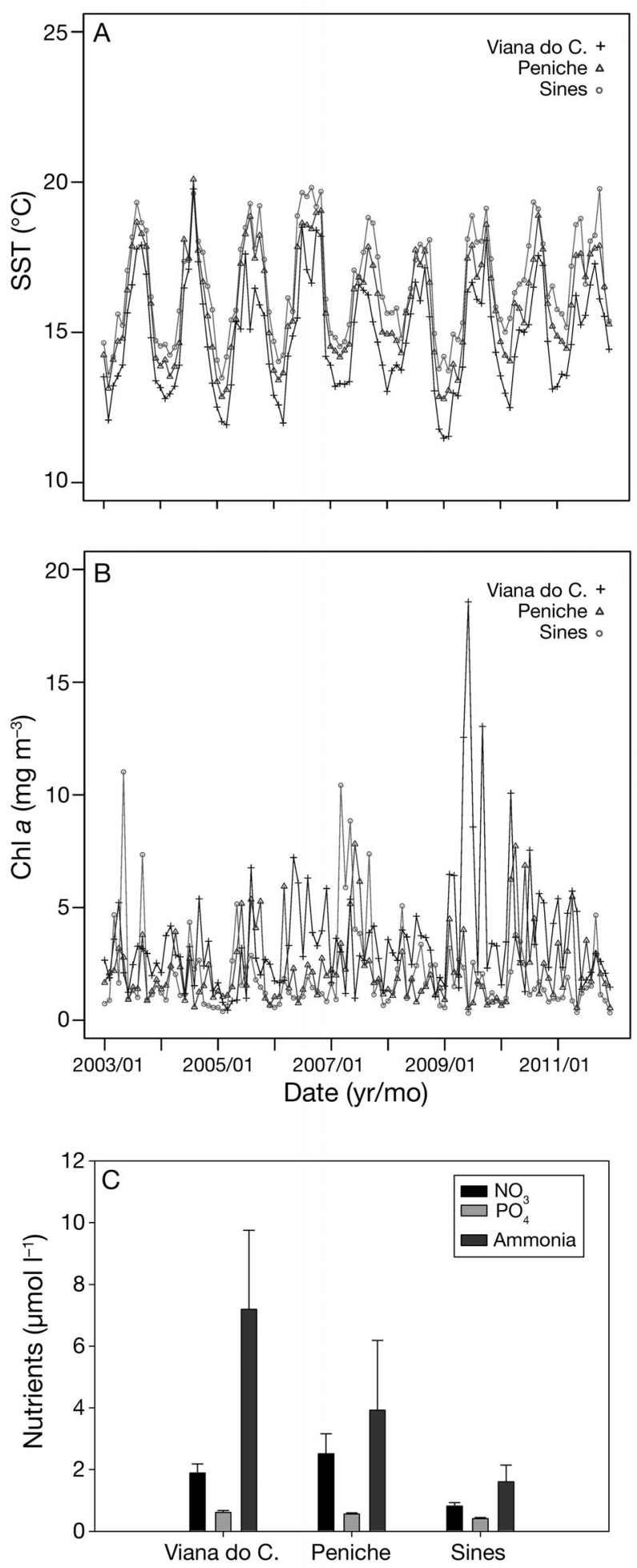

Fig. 2. Oceanographic patterns at 3 study regions along a latitudinal gradient in continental Portugal: (A) sea surface temperature (SST, $\mathrm{n}=103$ monthly values); (B) surface chl a concentration ( $\mathrm{n}=103$ monthly values); (C) concentration of nutrients immediately above the bottom $(\mathrm{n}=15$ samples per region). Error bars are SD of means. Viana do C.: Viana do Castelo
(Figs. 3A \& 4A) (2-way PERMANOVA, Region, $F_{(2,71)}=5.28, \mathrm{p}=0.0008$, Table 1). However, the landscape structure did not differ between PEN and SIN (Figs. 3A \& 4A; pairwise comparison, p > 0.05). Reefs at all regions were largely dominated by plateaus (Fig. 3B). VIA was the only region with conspicuous kelp forests (i.e. average coverage $>50 \%$, Fig. 3C), though the density of kelps was significantly higher at VIA relative to the other 2 regions only for Laminaria hyperborea (Fig. 3C) (2-way ANOVA, Region, $F_{(2,75)}=10.95, \mathrm{p}=0.0026$, Table 1). Densities of the kelps L. ochroleuca and Sacchoriza polyschides greatly varied among reefs, particularly at VIA, and this likely prevented detection of significant differences among regions (Fig. 3C) (2-way ANOVA, Region, $F_{(2,75)}=1.47, F_{(2,75)}=1.09$, for L. ochroleuca and $S$. polyschides respectively, p > 0.05 in both cases, Table 1). Phyllariopsis spp. was exclusively
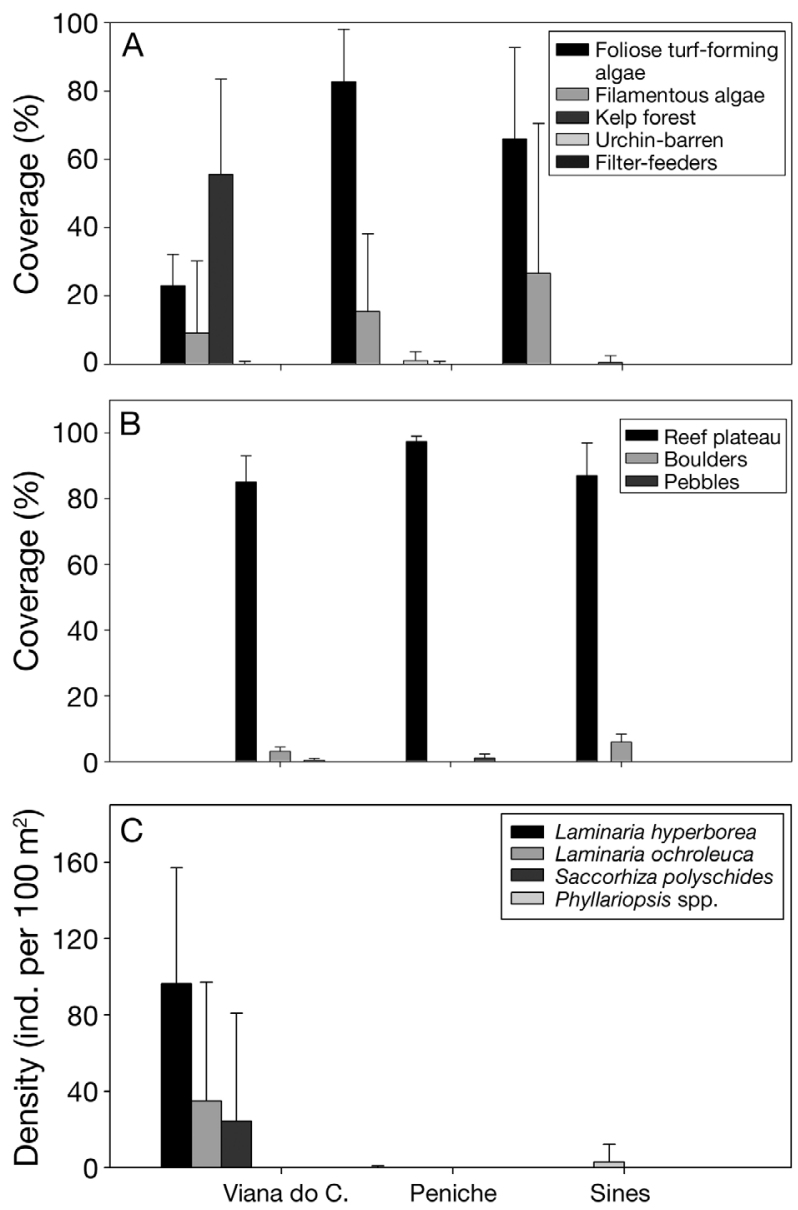

Fig. 3. Differences in (A) biogenic landscape structure, (B) bottom topography and (C) total kelp density between 3 study regions along a latitudinal gradient in continental Portugal ( $\mathrm{n}=30$ transects). Error bars are SD of means. Viana do C.: Viana do Castelo 

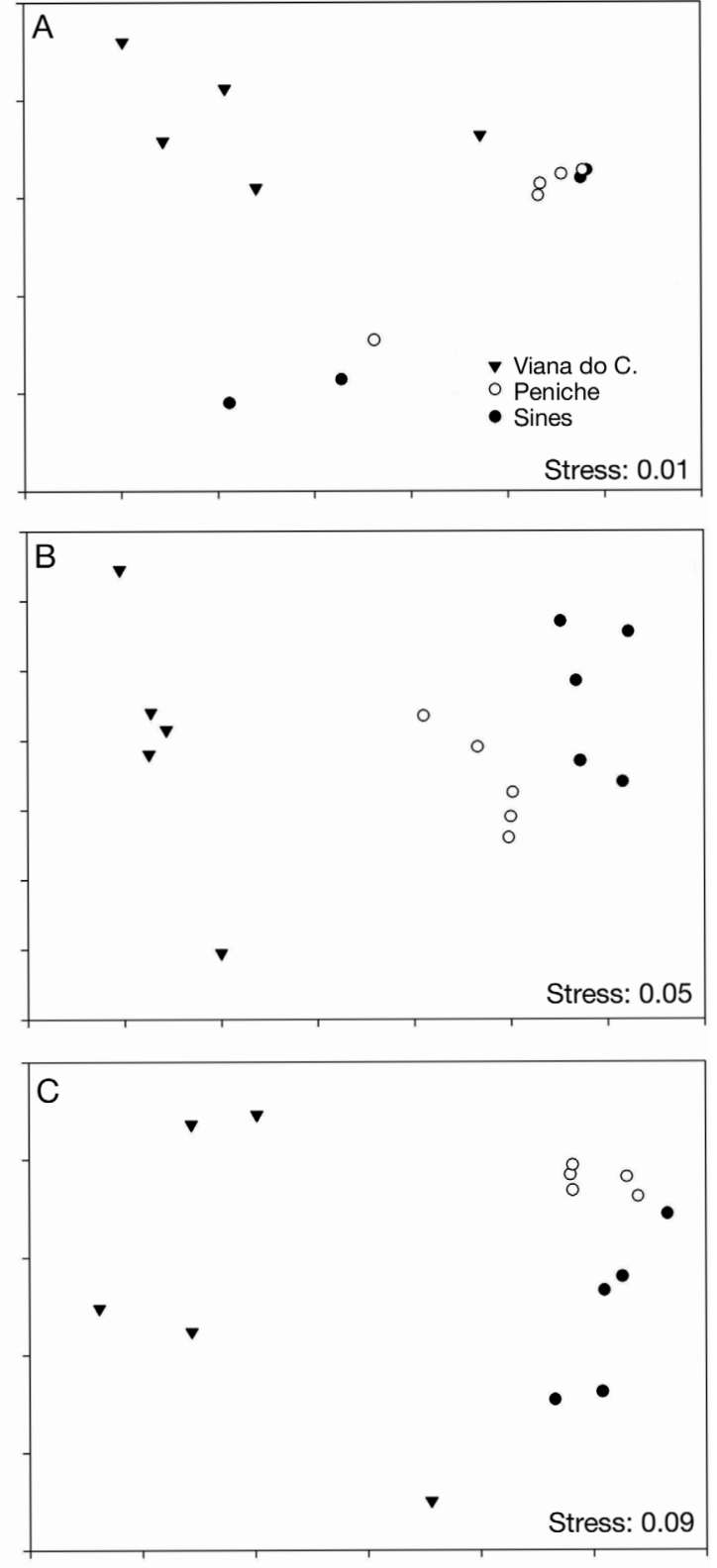

Fig. 4. Two-dimensional non-metric multidimensional scaling plot showing similarities between centroids of reefs within 3 study regions along a latitudinal gradient in continental Portugal for (A) biogenic landscape structure, (B) the structure of algal assemblages, and (C) the structure of fish assemblages. Viana do C.: Viana do Castelo

observed at SIN, though at small densities that prevented detection of significant differences at the scale of regions (Fig. 3C) (2-way ANOVA, Region, $F_{(2,75)}=2.15, \mathrm{p}>0.05$, Table 1$)$. In contrast to VIA, the landscapes at PEN and SIN were largely dominated by patches of foliose turf-forming and filamentous algae (Fig. 3A).

\section{Algal assemblages}

A total of 92 algal taxa were observed across continental Portugal in this study (Table S1 in the supplement) including 20 taxa growing as epiphytes on kelps. Significant differences in algal assemblage structure were observed among regions (2-way PERMANOVA, Region, $F_{(2,75)}=8.54, \mathrm{p}=0.0002$, Table 1). The algal assemblage structure differed between VIA and PEN and VIA and SIN (Fig. 4B; pairwise comparisons, $p<0.01$ ), but not between PEN and SIN (Fig. 4B; pairwise comparison, $p>$ 0.05). About $37 \%$ of the algal species observed at VIA were cold-water Atlantic boreal species (Fig. 5A, Table S1 in the supplement), whereas PEN and SIN were largely dominated by warm-water Lusitanian and widely distributed algal species (Fig. 5A, Table S1). The proportion of cold- versus warmwater species significantly differed between VIA and $\operatorname{PEN}\left(\chi_{1}^{2}=82.14\right)$ and VIA and $\operatorname{SIN}\left(\chi_{1}^{2}=114.07 ; \mathrm{p}<\right.$ 0.00001 in both cases), but did not differ between PEN and $\operatorname{SIN}\left(\chi_{1}^{2}=1.71, \mathrm{p}=0.2287\right)$.

\section{Fish assemblages}

A total of 25 fish species were encountered (Table S2 in the supplement). Significant differences in reef fish assemblage structure among regions was detected (2-way PERMANOVA, Region, $F_{(2,58)}=1.64$, $\mathrm{p}=0.0002$, Table 1). Pairwise comparisons indicated that fish assemblages from VIA were different from those observed at PEN and SIN ( $p<0.01$, Fig. 4B). More than one-third of the fishes at VIA were coldwater boreal species (Fig. 5B, Table S2), whereas species at PEN and SIN were mostly warm-water Lusitanian species (Fig. 5B, Table S2). The proportion of cold- versus warm-water species significantly differed between VIA and PEN $\left(\chi_{1}^{2}=5.00, \mathrm{p}=\right.$ $0.0251)$ and between VIA and $\operatorname{SIN}\left(\chi_{1}^{2}=7.16, p=\right.$ $0.0074)$ but did not differ between PEN and SIN $\left(\chi_{1}^{2}=2.16, p=0.1410\right)$.

\section{DISCUSSION}

\section{Latitudinal patterns}

Our results have demonstrated clear differences in the organization of the biogenic landscape and in the structure of 2 biological assemblages (algae and fishes) inhabiting subtidal reefs between northern Portugal (VIA) and central and southern Portugal 
Table 1. Results of multi- and univariate ANOVA testing the effects of Region and Reef within Region on the structure of the landscape, the structure of macroalgal and fish assemblages, and the density of 4 kelp species at 3 study regions along a latitudinal gradient in continental Portugal: Viana do Castelo (VIA), Peniche (PEN) and Sines (SIN)

\begin{tabular}{|c|c|c|c|c|c|}
\hline & df & MS & $F$ & $\mathrm{p}$ & $\begin{array}{c}\text { Pairwise } \\
\text { comparisons }\end{array}$ \\
\hline \multicolumn{6}{|c|}{ Landscape structure } \\
\hline Covariate & 4 & 3020.6 & 5.9848 & 0.0002 & \multirow{4}{*}{ VIA $\neq$ PEN, SIN } \\
\hline Region & 2 & 29110 & 5.2829 & 0.0008 & \\
\hline Reef (Region) & 12 & 6590.6 & 13.058 & 0.0002 & \\
\hline Residual & 71 & 504.71 & & & \\
\hline \multicolumn{6}{|c|}{ Algal assemblages } \\
\hline Region & 2 & 58084 & 8.5429 & 0.0002 & \multirow{3}{*}{$\mathrm{VIA} \neq \mathrm{PEN}, \mathrm{SIN}$} \\
\hline Reef (Region) & 12 & 6799.1 & 5.9805 & 0.0002 & \\
\hline Residual & 75 & 1136.9 & & & \\
\hline \multicolumn{6}{|c|}{ Fish assemblages } \\
\hline Covariate & 2 & 4128.4 & 1.6411 & 0.04 & \multirow{4}{*}{ VIA $\neq$ PEN, SIN } \\
\hline Region & 2 & 25765 & 5.8237 & 0.0002 & \\
\hline Reef (Region) & 12 & 4632.4 & 1.8415 & 0.0002 & \\
\hline Residual & 58 & 2515.6 & & & \\
\hline \multicolumn{6}{|c|}{ Laminaria hyperborea } \\
\hline Region & 2 & 92865 & 10.957 & 0.0026 & \multirow[t]{3}{*}{ VIA $>$ PEN, SIN } \\
\hline Reef (Region) & 12 & 8475.2 & 14.667 & 0.0002 & \\
\hline Residual & 75 & 577.82 & & & \\
\hline \multicolumn{6}{|l|}{ L. ochroleuca } \\
\hline Region & 2 & 12146 & 1.4725 & 0.2672 & \multirow[t]{3}{*}{-} \\
\hline Reef (Region) & 12 & 8248.3 & 46.882 & 0.0002 & \\
\hline Residual & 75 & 175.94 & & & \\
\hline \multicolumn{6}{|c|}{ Sacchoriza polyschides } \\
\hline Region & 2 & 5953.6 & 1.0909 & 0.429 & \multirow[t]{3}{*}{-} \\
\hline Reef (Region) & 12 & 5457.7 & 15.135 & 0.0002 & \\
\hline Residual & 75 & 360.6 & & & \\
\hline \multicolumn{6}{|c|}{ Phyllariopsis spp. } \\
\hline Region & 2 & 155.27 & 2.1542 & 0.0956 & \multirow[t]{3}{*}{-} \\
\hline Reef (Region) & 12 & 72.536 & 3.4667 & 0.0014 & \\
\hline Residual & 75 & 20.923 & & & \\
\hline
\end{tabular}

(PEN and SIN). Mean annual SST was negatively correlated with latitude across continental Portugal, as found by previous studies (Lemos \& Pires 2004, Lima et al. 2007), but this can only partially explain the corresponding changes in the organization of biological entities on reefs, as a number of other environmental factors typically covary across latitudinal gradients (Wernberg et al. 2011a). For example, our results showed that the decrease in SST with increasing latitude is accompanied by an increase in chl a and nutrient concentrations (except nitrates) across continental Portugal. This oceanographic gradient with latitude may partially explain differences among regions in the relative abundance of biogenic habitats and the assemblage structures of macroalgae and fishes. For example, the reproduction of kelps within the Laminariales significantly decreases under reduced nutrient availability and high temperatures (Bartsch et al. 2008, Pereira et al. 2011), which could then explain the absence of kelp beds at PEN and SIN in the present study. Importantly, however, our study revealed an abrupt change in the structure of the landscape and algal and fish assemblages from VIA to PEN and SIN, while the latter 2 regions were considerably similar from a macroecological perspective. Abrupt changes in topography, climate and/ or hydrography can explain sudden latitudinal changes in the composition and abundance of marine biota, e.g. fishes (Ojeda et al. 2000, Tolimieri \& Levin 2006). A cold-water 'pocket' encompassing northern Portugal (i.e. VIA) and south Galician waters has long been recognized as having an important influence on marine biota along this stretch of the coast (Southward et al. 1995, Peliz \& Fiúza 1999). Two previous studies (Ardré 1971, Lima et al. 2007), moreover, located a biogeographical discontinuity in the composition of intertidal algae in central Portugal, particularly between Cabo Carvoeiro $\left(39.2^{\circ} \mathrm{N}\right)$ (Ardré 1971) and the Nazaré Canyon $\left(39.6^{\circ} \mathrm{N}\right)$ (Lima et al. 2007). This discontinuity separates PEN and SIN, to the south, from VIA to the north. The Nazaré Canyon crosses the Portuguese continental margin from the coast to abyssal depths down to $4500 \mathrm{~m}$ (Fig. 1), intercepting slope sediment transport (Slagstad \& Wassmann 2001) and, most likely, along-shore routes of dispersion of marine organisms (King et al. 2008), with possible important consequences for past and current patterns of distribution of organisms across continental Portugal.

During the Pleistocene glaciations, the Atlantic Iberian coasts suffered a progressive cooling due to an intense displacement of the polar front towards lower latitudes (Crowley 1981). Many species currently living in the eastern Atlantic survived the cold phases of the glaciations in the adjacent Mediterranean, along north-western subtropical African coasts and Macaronesia, i.e. a southern refugia (Briggs 1974, Domingues et al. 2007). A subsequent replenishment of species from the south into north- 


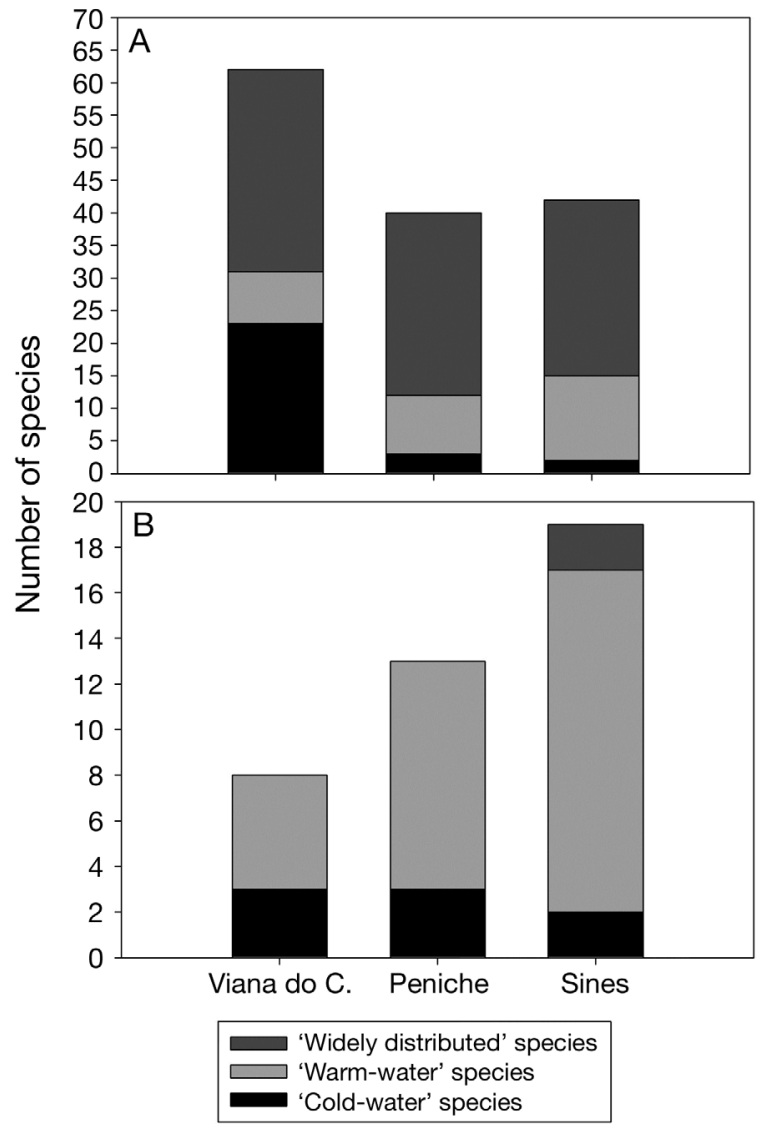

Fig. 5. Total number of (A) algal ( $\mathrm{n}=30$ quadrats) and (B) fish species ( $\mathrm{n}=25$ visual counts) at 3 study regions along a latitudinal gradient in continental Portugal. Viana do C.: Viana do Castelo

ern Atlantic waters occurred when temperature conditions turned favourable, i.e. during interglacial phases. However, the dispersal of species towards the northern Atlantic might have been limited by the Nazaré Canyon. This study confirmed previous findings that numerous cold-water macroalgal species are found north of this discontinuity, while species to the south are commonly found in the Mediterranean and in African waters (Ardré 1971, Lima et al. 2007; Table S1 in the supplement). Similarly, our results indicated that more than one-third of those fish species found to the north of this discontinuity (i.e. at VIA) are cold-water boreal species, while species found to the south (i.e. at PEN and SIN) were mostly warm-water Lusitanian species, widely found in the entire Mediterranean Sea and adjacent Atlantic waters (Froese \& Pauly 2008, Table S2 in the supplement).

At a global scale, the main habitat on temperate reefs is provided by laminarian (kelps) and fucalean canopy-forming algae. Kelps are cool-water species and relatively high temperatures have negative effects on their growth, survival and overall fitness, including reproduction and recruitment (Steneck et al. 2002, Wernberg et al. 2010, 2012, Merzouk \& Johnson 2011) - as reported for Laminaria ochroleuca and Sacchoriza polyschides in the NE Atlantic by Pereira et al. (2011). As a result, the abundance of kelps is expected to decrease with increasing ocean temperature. However, empirical evidence of the decrease in kelp abundance across latitudinal gradients of temperate coasts is lacking worldwide (Merzouk \& Johnson 2011). Our study revealed the presence of kelp forests at VIA, but not at PEN and SIN. Although the lack of previous quantitative subtidal sampling in continental Portugal prevents an adequate long-term comparison, there are local concerns, mostly based on anecdotic and personal observations along the entire coast of continental Portugal, that the abundance and distribution of kelps have been reduced in the last decades (Assis et al. 2009). For example, Laminaria hyperborea, a kelp with an affinity for cooler water, had its southern distribution limit at PEN in the 1970s (Ardré 1971) and 1980s (Izquierdo et al. 1993), while our surveys and those performed by Assis et al. (2009) observed this kelp exclusively in the waters off northern Portugal. This retreat in kelp presence matches a similar pattern observed along the north Iberian Peninsula (Fernández 2011), providing further support to the notion of a reduction of kelp forests along the Iberian Peninsula. In this context, there have been significant changes in the distribution of intertidal algae in the last decades across continental Portugal, with some warm-water species colonizing new areas (Lima et al. 2007). This pattern follows a global trend with cold-water species retreating poleward and a simultaneous advance of warm-water species (Helmuth et al. 2006), including seaweeds (Wernberg et al. 2011b). These distributional changes are correlated with the increase in SST, which has shown a steady year-round increase off continental Portugal from

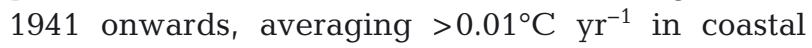
waters (Lemos \& Pires 2004, Lima et al. 2007). This increase in temperature has been explained by a decrease in the intensity of upwelling events from 1941 onwards, which has concurrently reduced the input of nutrient-enriched waters into the coast (Lemos \& Pires 2004). The relaxation of the upwelling has led to local advances northwards of some intertidal invertebrates, e.g. the limpet Patella rustica (Lima et al. 2006). This concomitant decrease in nutrient concentrations might also have negatively 
affected the performance of kelps across continental Portugal, since the reproduction of Laminariales is significantly reduced under reduced nutrient availability (Bartsch et al. 2008).

\section{Biogeographical implications: a reconfiguration of ecoregions?}

Ecoregions are areas with relative homogeneity in terms of their ecological systems, organisms and environment (Spalding et al. 2007). The Strait of Gibraltar was generally considered to divide 2 marine biogeographical regions: the Mediterranean Sea and the north-east Atlantic (Briggs 1974). Evidence to support this division was provided by studies on intraspecific genetic variation for a variety of organisms, including barnacles (Pannacciulli et al. 1997), fish (Naciri et al. 1999) and cephalopods (PérezLosada et al. 1999). However, a clear phylogenetic break has never been observed (Stamatis et al. 2004), and a relevant number of species show no genetic differentiation at all between Atlantic and Mediterranean populations (e.g. Bargelloni et al. 2003, Stamatis et al. 2004). More recently, the Strait of Gibraltar has been considered as a geographical pivotal point at the junction of 3 adjacent ecoregions (Spalding et al. 2007) within the temperate northern Atlantic realm: (1) the South European Atlantic Shelf, embracing the Atlantic Iberian Peninsula, (2) the Sahara upwelling off the west coast of Africa, both within the Lusitanian province, and (3) the Alboran Sea, within the Mediterranean province. The Alboran Sea is a small transitional ecoregion encompassing waters flowing from the Atlantic into the Western Mediterranean. A large number of species, moreover, have range edges in this ecoregion. This biogeographical configuration clearly recognizes Atlantic influences over Mediterranean waters, but neglects a reciprocal effect of Mediterranean waters over the biota inhabiting the adjacent Atlantic, which our results seem to suggest from a macroecological perspective. This suggests a possible reconfiguration of ecosystems that acknowledges the existence of a wider transitional area from the Atlantic into Mediterranean waters, involving either a sub-division of the South European Atlantic Shelf, or even a displacement of the division between the South European Atlantic Shelf and the Alboran Sea towards central Portugal, i.e. around the Nazaré Canyon. However, further data from southern Portugal and the north-west African coast would be required to reinforce this view.
Acknowledgements. Financial support was provided by the Portuguese Fundação para a Ciência e a Tecnologia (FCT) through the projects: 'Efeitos do clima oceânico na macroecologia e resiliência a perturbações dos povoamentos de kelps' - OCEANKELP (PTDC/MAR/109954/2009) and 'Responses to anthropogenic perturbations: climatic and nutrient effects on rock pool assemblages' - RAP (PTDC/ MAR/111223/2009), co-funded by the European Regional Development Fund (ERDF) through the 'Programa Operacional Factores de Competitividade' (POFC-COMPETE) within the 'Quadro de Referência Estratégico Nacional' (QREN). F.T. was supported while writing by the 'Ramón y Cajal' program from the Spanish Government. T.W. was supported by an Australian Research Council Future Fellowship. We thank Ocean Color Web (oceancolor.gsfc.nasa. gov/) from the NASA Goddard Space Flight Center for SST and chl a concentration data. B. Martínez and E. Bereicibar provided valuable criticism, while 4 anonymous reviewers provided insightful comments on a previous draft.

\section{LITERATURE CITED}

Alvarez M, Gallardo T, Ribera MA, Gómez-Garreta A (1988) A reassessment of Northern Atlantic seaweed biogeography. Phycologia 27:221-223

Anderson MJ (2001) Permutation tests for univariate and multivariate analysis of variance and regression. Can J Fish Aquat Sci 58:626-639

Anderson MJ, Gorley RN, Clarke KR (2008). PERMANOVA+ for PRIMER: guide to software and statistical methods. PRIMER-E, Plymouth

> Araújo R, Barbará I, Tibaldo M, Berecibar E and others (2009) Checklist of benthic marine algae and cyanobacteria of northern Portugal. Bot Mar 52:24-46

Ardré F (1971) Contribution a l'étude des algues marines du Portugal II. Ecologie et Chorologie. Bull Cent Etud Rech Sci Biarritz 8:359-574

Assis J, Tavares D, Tavares JT, Cunha AH, Alberto FA, Serrão EA (2009) Findkelp, a GIS-based community participation project to assess Portuguese kelp conservation status. J Coast Res 56:1469-1473

Barbará I, Cremades J, Calvo S, López Rodríguez MC, Dosil J (2005) Checklist of the benthic marine and brackish Galician algae (NW Spain). An Jardin Botanico Madr 1979 62:69-100

Bargelloni L, Alarcorn JA, Alvárez MC, Penzo E, Magoulas A, Reis C, Patarnello T (2003) Discord in the family Sparidae (Teleostei): divergent phylogeographical patterns across the Atlantic-Mediterranean divide. J Evol Biol 16: 1149-1158

Bartsch I, Wiencke C, Bischof K, Buchholz CM and 14 others (2008) The genus Laminaria sensu lato: recent insights and developments. Eur J Phycol 43:1-86

> Boaventura D, Ré P, Fonseca LC, Hawkins SJ (2002) Intertidal rocky shore communities of the continental Portuguese coast: analysis of distribution patterns. PSZN I: Mar Ecol 23:69-90

Boyce MS (1978) Climatic variability and body size variation in muskrats (Ondatra zibethicus) of North America. Oecologia 36:1-19

Briggs JC (1974) Marine zoogeography. McGraw-Hill, New York, NY

Brown JH (1984) On the relationship between abundance and distribution of species. Am Nat 124:255-279 
Brown JH, Maurer BA (1989) Macroecology: the division of food and space among species and continents. Science 243:1145-1150

Connell SD, Irving A (2008) Integrating ecology with biogeography using landscape characteristics: a case study of subtidal habitat across continental Australia. J Biogeogr 35:1608-1621

> Crowley TJ (1981) Temperature and circulation changes in the eastern north Atlantic during the last 150000 years: evidence from the planktonic foraminiferal record. Mar Micropaleontol 6:97-129

> Dayton PK, Tegner MJ, Parnell PE, Edwards PB (1992) Temporal and spatial patterns of disturbance and recovery in kelp forest community. Ecol Monogr 62:421-445

> Domingues VS, Santos RS, Brito A, Alexandrou M, Almada VC (2007) Mitochondrial and nuclear markers reveal isolation by distance and effects of Pleistocene glaciations in the northeastern Atlantic and Mediterranean populations of the white sea bream (Diplodus sargus, L.). J Exp Mar Biol Ecol 346:102-113

Fernández C (2011) The retreat of large brown seaweeds on the north coast of Spain: the case of Saccorhiza polyschides. Eur J Phycol 46:352-360

Fischer-Piette E, Prenant M (1957) Quelques données écologiques sur les cirripèdes intercotidaux du Portugal, de l'Espagne du sud et du nord du Maroc. Bull Cent Etud Rech Sci Biarritz 1:361-368

Froese R, Pauly D (eds) (2008) FishBase. www.fishbase.org

Graham MH (2004) Effects of local deforestation on the diversity and structure of southern California giant kelp forest food webs. Ecosystems 7:341-357

> Hawkins SJ, Sugden HE, Mieszkowska N, Moore PJ and others (2009) Consequences of climate-driven biodiversity changes for ecosystem functioning of North European rocky shores. Mar Ecol Prog Ser 396:245-259

> Helmuth B, Mieszkowska N, Moore P, Hawkins SJ (2006) Living on the edge of two changing worlds: forecasting the responses of rocky intertidal ecosystems to climate change. Annu Rev Ecol Evol Syst 37:373-404

> Irving AD, Connell SD (2006) Predicting understorey structure from the presence and composition of canopies: an assembly rule for marine algae. Oecologia 148:491-502

Izquierdo JL, Navarro MJ, Gallardo T (1993) Mapas de distribución de algas marinas de la Península Ibérica. IV. Laminaria ochoeroleuca (Pylaie), L. hyperborea (Gunner.) Foslie y L. saccharina (L.) Lamour. (Laminariales, Fucophyceae). Bot Complut 18:291-304

> King NJ, Jamieson AJ, Bagley PM, Priede IG (2008) Deepsea scavenging demersal fish fauna of the Nazaré Canyon system, Iberian coast, north-east Atlantic Ocean. J Fish Biol 72:1804-1814

> Last PR, White WT, Gledhill DC, Hobday AJ, Brown R, Edgar GJ, Pecl G (2011) Long-term shifts in abundance and distribution of a temperate fish fauna: a response to climate change and fishing practices. Glob Ecol Biogeogr 20:58-72

> Lemos RT, Pires HE (2004) The upwelling regime off the west Portuguese coast, 1941-2000. Int J Climatol 24: 511-524

> Lima FP, Queiroz N, Ribeiro PA, Hawkins SJ, Santos AM (2006) Geographic expansion of a marine gastropod, Patella rustica Linnaeus, 1758, and its relation with unusual climatic events. J Biogeogr 33:812-822

Lima F, Ribeiro PA, Queiroz N, Hawkins SJ, Santos A (2007) Do distributional shifts of northern and southern species of algae match the warming pattern? Glob Change Biol 13:2592-2604

Lüning K (1990) Seaweeds: their environment, biogeography, and ecophysiology. Wiley-Interscience, New York, NY

Merzouk A, Johnson LE (2011) Kelp distribution in the northwest Atlantic Ocean under a changing climate. J Exp Mar Biol Ecol 400:90-98

Naciri M, Lemaire C, Borsa P, Bonhomme F (1999) Genetic study of the Atlantic/Mediterranean transition in sea bass (Dicentrarchus labrax). J Hered 90:591-596

Ojeda P, Labra F, Muñoz A (2000) Biogeographic patterns of Chilean littoral fishes. Rev Chil Hist Nat 73:625-641

> Pannacciulli FG, Bishop JDD, Hawkins SJ (1997) Genetic structure of populations of two species of Chthamalus (Crustacea: Cirripedia) in the north-east Atlantic and Mediterranean. Mar Biol 128:73-82

> Parmesan C, Yohe G (2003) A globally coherent fingerprint of climate change impacts across natural systems. Nature 421:37-42

Peliz AJ, Fiúza AFG (1999) Temporal and spatial variability of CZCS-derived phytoplankton pigment concentrations off the western Iberian Peninsula. Int J Remote Sens 20: 1363-1403

Pereira SG, Lima FP, Queiroz NC, Ribeiro PA, Santos AM (2006) Biogeographic patterns of intertidal macroinvertebrates and their association with macroalgae distribution along the Portuguese rocky coast. Hydrobiologia 555:185-192

Pereira T, Engelen AH, Pearson G, Serrao E, Destombe C, Valero M (2011) Temperature effects on gametophyte development of $L$. ochroleuca and $S$. polyschides, kelps with contrasting life histories. Cah Biol Mar 52:395-403

Pérez-Losada M, Guerra A, Sanjuan A (1999) Allozyme differentiation in the cuttlefish Sepia officinalis (Mollusca: Cephalopoda) from the NE Atlantic and Mediterranean. Heredity 83:280-289

> Philippart CJM, Anadón R, Danovaro R, Dippner JW and others (2011) Impacts of climate change on European marine ecosystems: observations, expectations and indicators. J Exp Mar Biol Ecol 400:52-69

Poloczanska ES, Babcock RC, Butler A, Hobday AJ and others (2007) Climate change and Australian marine life. Oceanogr Mar Biol Annu Rev 45:407-478

> Roy K, Jablonski D, Valentine JW, Rosenberg G (1998) Marine latitudinal diversity gradients: tests of causal hypotheses. Proc Natl Acad Sci USA 95:3699-3702

Santos AM (2000) Intertidal ecology of northern Portuguese rocky shores. PhD thesis, University of Southampton

Schiel DR, Foster MS (1986) The structure of subtidal algal stands in temperate waters. Oceanogr Mar Biol Annu Rev 24:265-307

Slagstad D, Wassmann P (2001) Modelling the 3-D carbon flux across the Iberian margin during the upwelling season in 1998. Prog Oceanogr 51:467-497

> Southward AJ, Hawkins SJ, Burrows MT (1995) Seventy years' observations of changes in distribution and abundance of zooplankton and intertidal organisms in the western English Channel in relation to rising sea temperature. J Therm Biol 20:127-155

Spalding MD, Fox HE, Allen GR, Davidson N and others (2007) Marine ecoregions of the world: a bioregionalization of coastal and shelf areas. Bioscience 57:573-583

Stamatis C, Trianfylidis A, Moutou KA, Mamuris Z (2004) Mitochondrial DNA variation in Northeast Atlantic and 
Mediterranean populations of Norway lobster, Nephrops norvegicus. Mol Ecol 13:1377-1390

Steneck RS, Graham MH, Bourque BJ, Corbett D, Erlandson JM, Estes JA, Tegner MJ (2002) Kelp forest ecosystems: biodiversity, stability, resilience and future. Environ Conserv 29:436-459

ter Hofstede R, Rijnsdorp AD (2011) Comparing demersal fish assemblages between periods of contrasting climate and fishing pressure. ICES J Mar Sci 68: 1189-1198

Tolimieri N, Levin PS (2006) Assemblage structure of Eastern Pacific groundfishes on the US continental slope in relation to physical and environmental variables. Trans Am Fish Soc 135:317-332

Tuya F, Duarte P (2012) Role of food availability in the bathymetric distribution of the starfish Marthasterias glacialis (Lamk.) on reefs of northern Portugal. Sci Mar 76:9-15

Tuya F, Haroun RJ (2006) Spatial patterns and response to wave exposure of shallow water algal assemblages across the Canarian Archipelago: a multi-scaled approach. Mar Ecol Prog Ser 311:15-28

> Tuya F, Wernberg T, Thomsen MS (2008) The spatial arrangement of reefs alters the ecological patterns of fauna between interspersed habitats. Estuar Coast Shelf Sci 78:774-782

Tuya F, Wernberg T, Thomsen MS (2009) Habitat structure affect abundances of labrid fishes across temperate reefs in south-western Australia. Environ Biol Fishes 86: 311-319

Tuya F, Wernberg T, Thomsen MS (2011) The relative influence of local to regional drivers of variation in reef fishes. J Fish Biol 79:217-234

Underwood AJ (1997) Experiments in ecology: their logical

Editorial responsibility: Lisandro Benedetti-Cecchi, Pisa, Italy design and interpretation using analysis of variance. Cambridge University Press, Cambridge

Walther GR, Post E, Convey P, Menzel A and others (2002) Ecological responses to recent climate change. Nature 416:389-395

Waters JM, Wernberg T, Connell SD, Thomsen MS and others (2010) Australia's marine biogeography revisited: Back to the future? Austral Ecol 35:988-992

> Wernberg T, Kendrick GA, Toohey BD (2005) Modification of the physical environment by an Ecklonia radiata (Laminariales) canopy and implications for associated foliose algae. Aquat Ecol 39:419-430

Wernberg T, Thomsen MS, Tuya F, Kendrick GA, Staehr PA, Toohey BD (2010) Decreasing resilience of kelp beds along a latitudinal temperature gradient: potential implications for a warmer future. Ecol Lett 13:685-694

> Wernberg T, Thomsen MS, Tuya F, Kendrick GA (2011a) Biogenic habitat structure of seaweeds change along a latitudinal gradient in ocean temperature. J Exp Mar Biol Ecol 400:264-271

Wernberg T, Russell B, Thomsen MS, Gurgel FG, Bradshaw CJA, Poloczanska ES, Connell SD (2011b) Seaweed communities in retreat from ocean warming. Curr Biol 21: 1828-1832

Wernberg T, Smale DA, Tuya F, Thomsen MS and others (2012) An extreme climatic event alters marine ecosystem structure in a global biodiversity hotspot. Nat Clim Change doi:10.1038/NCLIMATE1627

Wheeler AC, Merrett NR, Quigley DTG (2004) Additional records and notes for Wheeler's (1992) List of the common and scientific names of fishes of the British Isles. J Fish Biol 65 (Suppl B):1-40

Witman JD, Roy K (2009) Marine macroecology. The University of Chicago Press, Chicago, IL

Submitted: April 10, 2012; Accepted: July 13, 2012

Proofs received from author(s): October 8, 2012 